\title{
Pancreatic nutritional response of preruminant calves: effects of different treated soybean diets
}

\author{
G Le Dréan, I Le Huërou-Luron, V Philouze-Romé, R Toullec, P Guilloteau
}

INRA, Laboratoire du Jeune Ruminant, 65, rue de Saint-Brieuc, 35042 Rennes Cedex, France

The replacement of skim milk by soybean products in the diet given to preruminant calves has been shown to decrease pancreas size and protease secretions (Gorrill et al, 1967; Guilloteau et al, 1986). The aim of the present experiment was to study the effects of soybean products differing by their protein and carbohydrate contents and their antigenic activity on the pancreas enzyme activities and the corresponding messenger RNA (mRNA).

One group of 7 Holstein bull calves $30 \mathrm{~d}$ old were given for $105 \mathrm{~d}$ milk substitutes in which proteins were provided exclusively by dairy products (CTL). Three other groups received milk substitutes in which $70 \%$ of dairy proteins were replaced with proteins provided by a heated soybean flour (HSF) or a water extracted concentrate (WEC) or a partially hydrolyzed isolate (PHI).

In the HSF group, 2 animals died and 1 was excluded due to large refusals. At the end of the experiment, liveweight (mean $\pm S E$ ) was lower with the soybean diets $(136 \pm 12 \mathrm{~kg}, 145 \pm 4 \mathrm{~kg}$, and $157 \pm 4 \mathrm{~kg}$ for HSF, WEC and PHI, respectively) than with CTL diet $(166 \pm 2 \mathrm{~kg})(P \leq 0.05$ between HSF or WEC and CTL). The pancreas weight tended (NS) to be lower with the soybean diets $(691 \pm 34,633 \pm 43,640 \pm 32 \mathrm{mg} / \mathrm{kg}$ liveweight instead of $710 \pm 31$ ); a similar tendency was recorded for the chymotrypsin and amylase activities, but only the difference for amylase between the PHI and the CTL diets was closed to the significance (table I). That trend was not apparent for the trypsin activity (data not shown). In the present experiment, the soybean products had less effects on the pancreas weight and protease activities than those recorded by Gorrill et al (1967) and Guilloteau et al (1986). In contrast, the decreased amylase activity has not been observed by these authors and could be related to the elimination of soybean carbohydrates in PHI. The relative mRNA levels were not significantly affected by soybean diets, but they all tended to be higher with the HSF diet. However, these variations were insufficient to indicate the mechanisms involved in the pancreas response to different soybean products. Further investigations are required.

Gorrill ADL, Thomas JW, Stewart WE, Morrill JL. (1967) J Nutr 92, 86-92

Guilloteau P, Corring T, Chayvialle JA, Bernard C, Sissons JW, Toullec R (1986) Reprod Nutr Develop 26, 717-728

Table l. Effects of different soybean diets on the pancreas (means \pm SE).

\begin{tabular}{|c|c|c|c|c|}
\hline Diet (antigenicity) & CTL (-) & $P H I(-)$ & WEC (t) & $H S F(++)$ \\
\hline $\begin{array}{l}\text { Pancreatic protein (mg/kg liveweight) } \\
\text { Enzyme activity ( } \mathrm{kU} / \mathrm{kg} \text { liveweight) }\end{array}$ & $103 \pm 5$ & $98 \pm 5$ & $83 \pm 7$ & $90 \pm 6$ \\
\hline $\begin{array}{l}\text { Amylase } \\
\text { Chymotrypsin }\end{array}$ & $\begin{aligned} 0.74 & \pm 0.07 \mathrm{a} \\
4.4 & \pm 0.6\end{aligned}$ & $\begin{aligned} 0.49 & \pm 0.05 b \\
2.9 & \pm 0.3\end{aligned}$ & $\begin{array}{l}0.52 \pm 0.09 \\
2.7 \pm 0.7\end{array}$ & $\begin{aligned} 0.75 & \pm 0.14 \\
2.6 & \pm 0.3\end{aligned}$ \\
\hline $\begin{array}{l}\text { Specific mRNA* } \\
\text { Amylase } \\
\text { Chymotrypsin }\end{array}$ & $\begin{array}{l}1.00 \pm 0.19 \\
1.00 \pm 0.09\end{array}$ & $\begin{array}{l}1.27 \pm 0.20 \\
1.23 \pm 0.15\end{array}$ & $\begin{array}{l}1.13 \pm 0.14 \\
1.24 \pm 0.09\end{array}$ & $\begin{array}{l}1.50 \pm 0.39 \\
1.76 \pm 0.41\end{array}$ \\
\hline
\end{tabular}

" The level of each specific mRNA was normalized to that in control. a,b Different from control values $(0.05<P<0.1)$. 